\title{
SMA と柔軟プレートを組み合わせた四脚移動ロボットの開発*
}

\author{
西田麻美** \\ Development of the Quadruped Locomotion Robot using Shape Memory Alloy and Flexible Plate
}

\section{Mami NISHIDA}

\begin{abstract}
In this paper, the author described a quadruped locomotion robot using a shape memory alloy (SMA) and a flexible plate. First, "Flexible Flat Plate (FFP)" actuator which consisted of the SMA and a thin polyethylene plate was investigated. The locomotion robot was manufactured by combining with a mechanism to drive the legs. Next, the author proposed a method of generating the gait of the robot, and experimentally clarified the simple ON-OFF input-and-output signal timing. The advance and retreat of the robot were possible by changing the phase of the input signal timing. Finally, a walking experiment and a payload experiment were carried out and the effect of the generated ON-OFF input-and-output signal timing was considered. This paper presented a palm-sized quadruped locomotion robot with back-and-forth movement and easy switching of the ON-OFF controls. This robot was able to move at least $30 \mathrm{~mm}$ in $30 \mathrm{sec}$. The robot has the potential to be used in high and low temperatures or where corrosive gases are generated.
\end{abstract}

Key words: quadruped locomotion robot, ON-OFF control, FFP actuator, soft robot, SMA

\section{1. 緒言}

温度変化により元の形状に回復する機能を持つ形状記憶合金 （SMA）は, 軽量小型化が可能で, 形状回復ひずみや駆動温度 範囲が大きく，耐食性や耐疲労性にも優れていることから温度 センサを兼衫るアクュエータ材料として生活・家電製品, 医 療用品を始め, 多くのロボットに利用されている. 例えば， チ タン（Ti）とニッケル $(\mathrm{Ni})$ を成分とする SMA を用いたロボ ットは, 手術用のマニピュレータ 1) 2)やロボットハンド3) 4)など に多く応用されており, 数は少ないが, 移動機構に SMA を用い たロボットの研究 5) 6)などその活躍は多岐に渡っている. 通常, SMA をアクチュエータとして利用する場合, 加熱・冷却による 応答性が課題となるが, 線径や表面積を小さくすることで応答 速度の向上を試みた研究 7) や温度制御のための熱伝導モデルを 用いた解析8)など改善が進められている。一方で, Ti-Ni 系合金 における形状記憶合金の実用化が 1980 年代に始まって以来, 形 状記憶合金の形状回復温度は約 $353 \mathrm{~K}$ 程度に制限されていた。

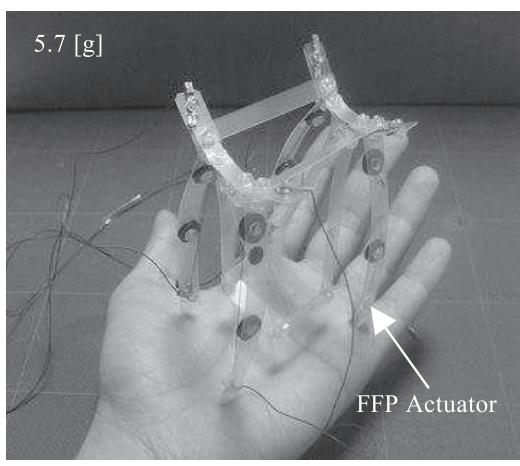

Fig.1 Flexible quadruped locomotion robot

\footnotetext{
* 原稿受付 平成 24 年 6 月 19 日

** 正会員 関東学院大学（神奈川県横浜市金沢区六浦東 1-50-1)
}

\begin{abstract}
そのため, 比較的高い周囲温度下で利用することは原理的に不 可能であった。 この問題に対し, 近年では, Ti-Pt, Ti-Au など の白金族やジルコニウムを含む形状記憶材料に着目し, 超急冷 法により機械的特性を向上させた高温形状記憶合金が開発され てきている 9）10)。仮に，高低温領域で利用できる腐食性に優れ たロボットが実現できれば, 高温・冷帯地域における環境探査 やガス・液体を分析調査するマシンとして期待できる. そこで 筆者は, 高而熱性および非導電性のポリエチレンプレート(板厚 $0.35 \mathrm{~mm}$ )とプレートを湾曲駆動するための駆動源 (SMA アクチ ユエータ)を組み合わせた Flexible Flat Plate (FFP)アクチュエ 一タを製作した. 次に, 移動機構を実現するため, FFP アクチ ユエータを脚およびボディとして一体化し, ボディの内側へと プレートを可変させることで推進力を得られる四脚移動ロボッ 卜を試作した（図 1）。本論文では，ロボットの構成ならびに 歩行原理について説明するとともに, 単純な ON-OFF 制御によ つて, 前進・後退運動を実現できる脚式ロボットの歩行実験と その結果について報告する.
\end{abstract}

\section{2. 四脚移動ロボットの構成}

SMA は電圧印加に依存して伸縮する性質を持っている. その 伸縮に伴って可変する可撓性材料と SMA とを組み合わせて, 口 ボットのアクチュエータおよびボディとして構成する. 本研究 では, 可撓性材料として加工性に優れたポリエチレンプレート を採用し，リンク状に切り出したものに SMA 張り合わせた。 こ れを Flexible Flat Plate (FFP)アクチュエータと称する.この FFP アクチュエータを垂直方向に 4 枚並べ, ボディ構造として 構成することで駆動源を含めた簡単な移動機構が可能となる. $\mathrm{ON}$ 時には，一方向にプレートが弓なりに湾曲し，OFF 時によ ってプレートに蓄積されたエネルギーを SMA の復元に伴って 放出するメカニズムで歩行運動を試みる.また, 電流・電圧に よる ON-OFF制御によってプレートの湾曲状態を変化させてい るため, 歩行に必要な方向転換を単純な制御で容易に変更する ことも可能である．以下にロボットに用いた材料の詳細につい 
て述べる.

（i）形状記憶合金(SMA)

現在, 高温域で使用できる SMA は開発段階であるため, $290 \mathrm{~K}$ 〜350K の温度で収縮する Ti-Ni 系の SMA として, トキコーポ レーション製のバイオメタル BMF250 (線径 $0.25 \mathrm{~mm}$ )を採用す る. BMF250 ワイヤは, $296 \mathrm{~K}$ の室温おいて $3.0 \mathrm{~V} / 0.7 \mathrm{~A}$ の電圧 印可で約 4\%収縮する. BMF 250 を全長 $60 \mathrm{~mm}$ に裁断し，両端 にプレートへと固定するための圧着端子を取り付けた.

(ii) ポリエチレンプレート

移動機構を実現するために, SMAにより動作し，かつ，載荷 方向による強度や剛性を確保できる材料として, 高耐熱性およ び非導電性に優れたポリエチレンプレート板厚 $0.35 \mathrm{~mm}$, 幅 $6 \mathrm{~mm}$, 全長 $80 \mathrm{~mm}$, ヤング率 $4.0 \mathrm{Gpa}$, ポアソン比 0.44 のダイ ヤホイル S100-350(三菱化学製ポリエチレンフィルム社製)を用 いた．本プレートは，金属などと比較して低コストで自由に設 計・加工できる利点がある．ポリエチレンの中でも約 $150 \%$ と 伸展性が高く, 吸水率 $0.3 \%$, 使用可能範囲温度が約 $203 \mathrm{~K} \sim$ $473 \mathrm{~K}$ であるため, 幅広い環境下で応用できる. また, アセトン, ベンゼン, 硫酸, 塩酸など強化学薬品にも長時間対応できるた

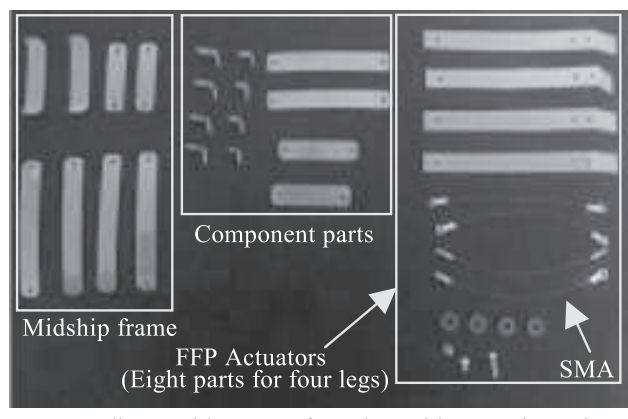

Fig.2 All assembly parts of quadruped locomotion robot

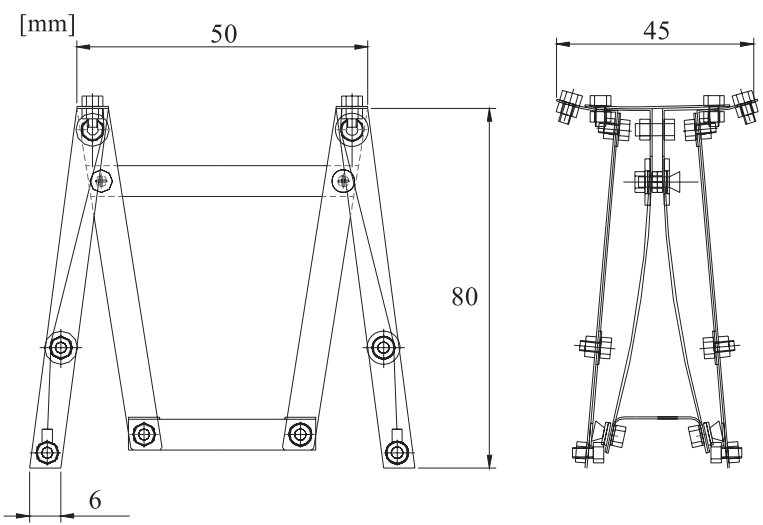

Fig.3 Assembly of quadruped locomotion robot

Table.1 Specifications of the Developed Quadruped robot

\begin{tabular}{|c|c|}
\hline Degree of freedom & 4 \\
\hline Dimensions & $50 \mathrm{~L} \times 45 \mathrm{~W} \times 80 \mathrm{Hmm}$ \\
\hline Weight & $5.7 \mathrm{~g}$ \\
\hline Payload & $7.41 \mathrm{~g}$ \\
\hline Power supply & $3.0 \mathrm{~V} / 0.7 \mathrm{~A}$ \\
\hline Material & Polyethylene \\
\hline
\end{tabular}

め, ガスや液体が発生している特殊な環境や腐食が厳しい場所 で用いる材料として期待できる。ここで，ロボットを構成する 主な部品を図 2 に示す. まず，ロボットの脚となる FFPアクチ ユエータは，先に述べた(i)と(ii)を SMA のテンションが緩まな いように耐熱プーリを介して耐熱樹脂のネジおよびナットで固 定する. 次に，4つの FFP アクチュエータを SMA が内側にな るように垂直に配置し，一定の幅を置いて同ポリエチレンプレ 一トで組み合わせる，ついで，バッテリーや制御基板などの塔 載スペースを考慮して, ロボットの中央部に重量物エリアを確 保する. 図 3 に四脚移動ロボットの正面図および側面図, 表 1 にロボットの仕様を示す. 試作したロボットは, 3.0V/0.7Aによ って一脚が駆動される. 全高 $80 \mathrm{~mm}$, 横幅 $45 \mathrm{~mm}$, 奥行幅 $50 \mathrm{~mm}$, 総質量 $5.7 \mathrm{~g}$ と小型軽量のため, 人間の手のひらに納まるほどの 大きさである。

\section{3. 四脚移動ロボットの歩行原理}

歩行ロボットの課題の一つは, 歩容を決定することである. そこで，四脚移動ロボットが機能的に移動するための歩容につ いて述べる.一般的に用いられているインチワーム機構では, 自由度の増加に伴い制御素子の増加，装置の大型化，複雑化な どの問題が生じる. 本ロボットでは，垂直方向に伸縮するリン ク（関節レス）と単純な入出信号タイミングのみで，左右・前 後・旋回運動ができる。まず，平坦な水平面において，ロボッ トが直進する時の歩容原理について説明する。ここでは，ロボ ットの重心がその幾何学的中心にあると仮定し, 各脚は一定の 脚軌道を繰り返し動くものとする. また，静的安定性が保持さ れるように, 常に 3 本以上の脚が地面と接地する構造とする. さらに，4つの FFPアクチュエータが湾曲時（遊脚）から回復 時（支持脚）に変わる場合でも，互いにエリアを確保できるよ うな立脚設計とする. 図 4 は, 歩容生成のための実験システム である. 制御システムは, ワンチップマイクロコンピュータを 用いた駆動回路およびパワー回路から構成される. 眓に示され る破線は SMA を表す. SMA の両端部に電圧印可すると 4 つの 脚は，それぞれロボット機体の内側に湾曲する。進行方向に向 かって, 左後脚を $\mathrm{EC} 1$, 左前脚を $\mathrm{EC} 2$, 右後脚を $\mathrm{EC} 3$, 右前脚 を EC4 とする.この実験システムより $\mathrm{EC} 1 \rightarrow \mathrm{EC} 2 \rightarrow \mathrm{EC} 3 \rightarrow \mathrm{EC} 4$ の順にオープンループによって ON-OFF入出力信号を連続的に 繰り返す. 図 5 に四脚移動ロボットの歩容パターンについて示 寸. 図の（1）から（5）はロボットの上面図および側面図であ り， $x$ 方向が進行方向である. 正面の眓より左後脚から EC1, 左前脚を $\mathrm{EC} 2$, 右後脚を $\mathrm{EC} 3$, 右前脚を $\mathrm{EC} 4$ とする. 次に歩 行パターンの策について述べる.

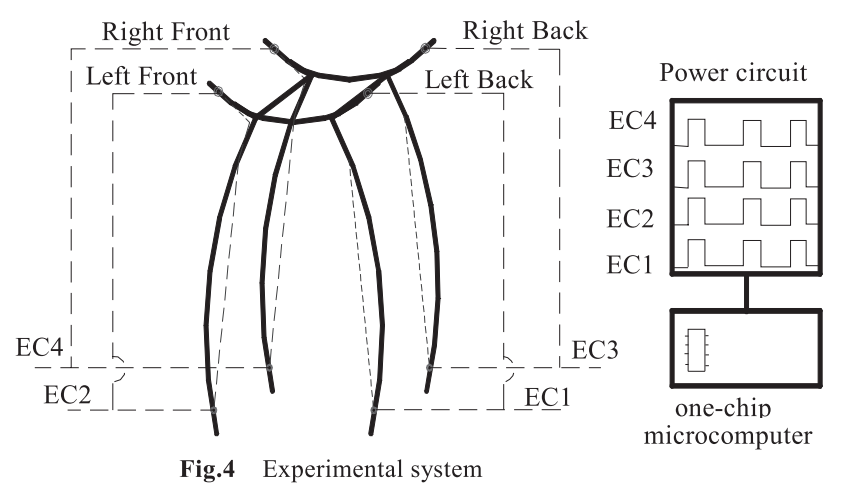



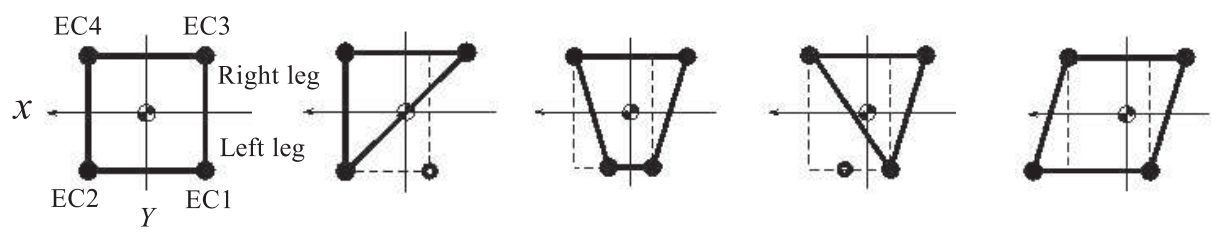

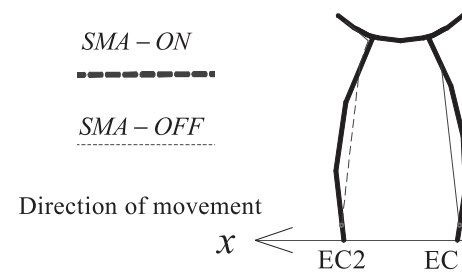

(1)

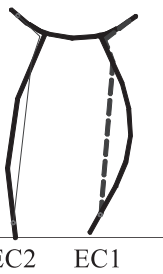

(2)
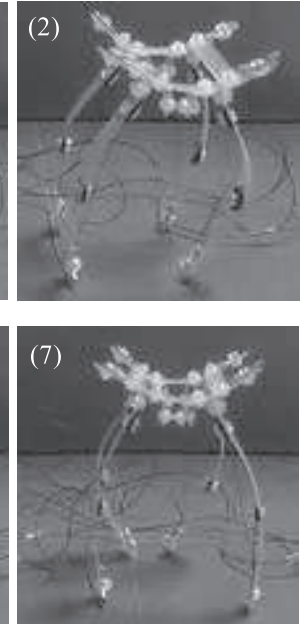
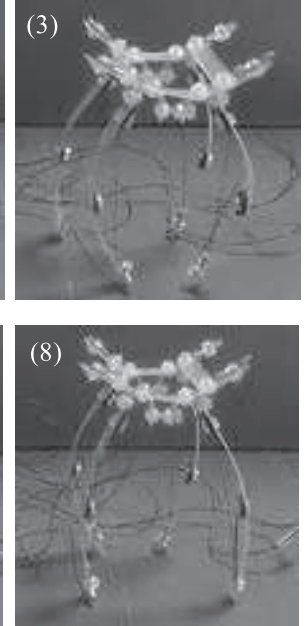
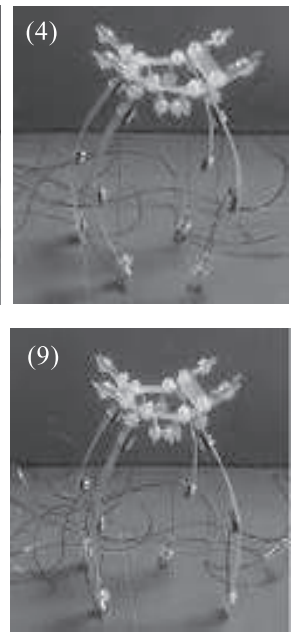

Fig.6 Changing locomotion modes considering walking gaits
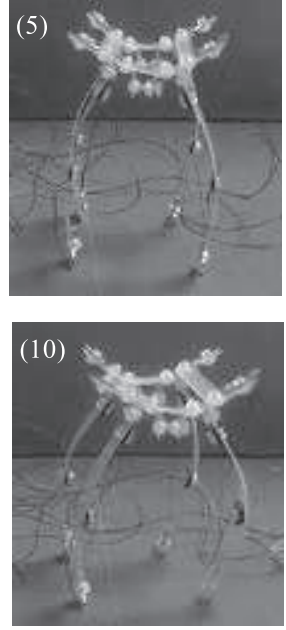

$\mathbf{X}_{\text {STARTLINE }}$
図 5(1)では，四脚移動ロボットが接地面に支持しており， 胴体中心は中央に位置している，ここで, 左後脚（EC1）に電 圧印可すると，図 5(2)のように，SMA が収縮し，それに伴っ てプレートが推進方向に湾曲して遊脚となり, EC2, EC3, EC4 の 3 脚が支持脚となる. 次に, 左後脚（EC1）の変形状態を保 持したまま（SMA の電圧解除せずに）左前脚（EC2）に電圧 印可する. これよって EC2 のプレートが湾曲し, その直後, $\mathrm{EC} 1 ， \mathrm{EC} 2$ それぞれが湾曲状態で地面に接地する（図 5(3)）。 この時, 左側の二脚が図のように内側へ閉じた状態，右側の 二脚は (1)の状態で支持する. 続いて, 図 5(4)にて, 左後脚 (EC1) の SMA の電圧を解除するとプレートの復元力によって 脚が元の形状一戻る. ここでは, 前右脚 (EC2) の从が遊脚と なる. 図 5 （5）にて, 左後脚 (EC1)のプレートが完全に原 型回復されたタイミングで, 左前脚（EC2）の電圧を解除 し， $x$ 前方へを開脚させる。この手順を右脚（EC3，EC4） においても同様に行う. 図 6 に四脚移動ロボットの歩容動 作を示す．（1）から(5)までが左脚，（6)から（10）までが右 脚の移動の様子である. (10)にてスタートラインから EC1, EC3 で得たひずみ量分前進していることがわかる．この夕 イミングを繰り返すことで歩行動作を達成する。なお, 後退においては, 前脚と後脚の手順を逆に変更するだけ でよい.

\section{4. 歩行のための ON-OFF 入出カタイミング信号}

四脚移動ロボットの動作は, 切り出したポリエチレンプレー トとプレートを湾曲させるためのSMAに大きく依存する．した がって, 電圧印可 (ON時) による脚の最大ひず夕から電圧解除 (OFF時) による脚の復元（初期の状態）までに要する時間を 考慮して歩行のための信号タイミングを決定する必要がある. そこで, FFPアクチュエータの挙動について実験を試みる. 実験 は，図7に示すようにFFPアクチュエータを片持ち梁に見立て， 繰り返し負荷を与える.プレートの長さを $L$ とした時, SMAへ 入出力信号を繰り返し行うことで得られるON，OFFそれぞれの 時間とプレート先端の最大ひずみ量 $w$ と $u$ を計測する。ここ で, $w$ は脚の歩幅, $u$ は振り上げ高さを意味する. FFPアク チュエータのたわみ量は, 電圧印加の違いによってロボットの

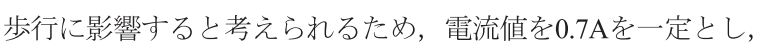
$2.0 \mathrm{~V} ， 2.5 \mathrm{~V} ， 3.0 \mathrm{~V} ， 3.5 \mathrm{~V} ， 4.0 \mathrm{~V}$ とそれぞれ最大たわみ量を得る まで電圧印加を行い, その後, 電圧解除により自然放冷させて 初期状態に形状回復させる. これを 1 サイクルとする. この状 況を2台のカメラを用いた3次元画像処理装置で測定寸る. 実験 結果を図8に示す．常温時(296K)のステップ忘答に対して, FFP アクチュエータは, どの電圧でもほぼ同じ変位量が確認された. また， $x$ 方向に対して最大たわみ $w$ が約 $23 \mathrm{~mm}, \quad u$ は約 $7 \mathrm{~mm}$ 


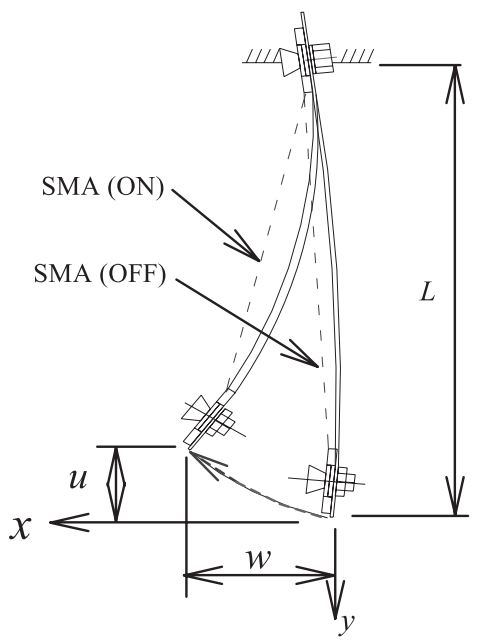

Fig.7 Deflection property of FFP (Beam shape)
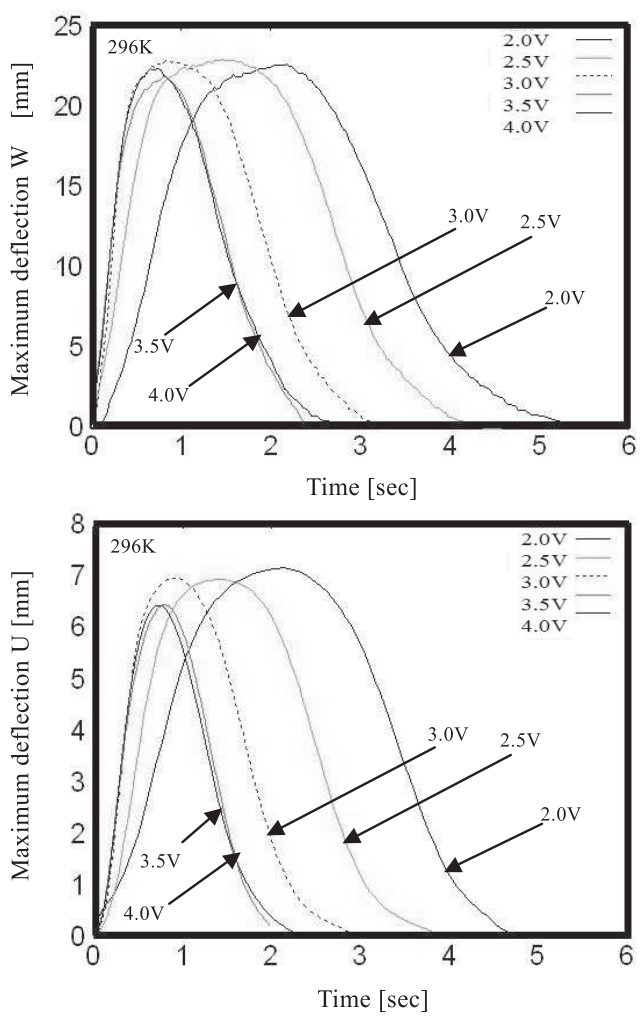

Fig.8 Distortion characteristics for voltage change

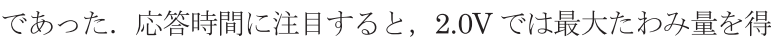
るまでに約 2 秒以上を要し，そこから初期状態に戻り安定する までに約 4 秒かかった。 ついで， $2.5 \mathrm{~V} ， 3.0 \mathrm{~V}$ と増すごとに， 1 秒刻みで戻りが早くなり， $3.5 \mathrm{~V}$ 以上では同じ挙動であった。 ま た， $u$ 方向では， $3.5 \mathrm{~V}$ 以上になるとたわみ量が若干減少した. この結果を基に，ロボットを簡易的に歩行させたところ $4.0 \mathrm{~V}$ ， $3.5 \mathrm{~V}$ では収束する前に転倒がみられ, $2.0 \mathrm{~V}$ では反応が遅いため $w$ および $u$ 方向にプレートが十分に湾曲せず，移動速度に影響 を及ぼした，そこで， $3.0 \mathrm{~V}$ を採用して歩行を実現するための ON-OFF 信号タイミングを決定した. 図 9 に四脚移動ロボット の基本歩容における ON-OFF タイミングチャートを示寸. 本機 のようなソフト歩行ロボットは，人間の歩行と同じように遊脚 から脚への着地点が常に同じとは限らず，またヒステリシスや 歩行面でのガタ (外乱) の影響によって, 床と脚底の摩擦が増
減を繰り返し，歩行の途中でバランスを崩すことがある，そこ で，ON 信号では高速に，OFF 信号時では，変形された脚が十 分に復元するまでの時間を考慮して，ON 時では最大ひずみを 得る 1 秒に加えて 2 秒の追加, OFF 時では, 約 2 秒の回復から 開脚によって地面と垂直な安定姿勢となる時間の 2 秒を加えて 信号タイミングの調整を施した.

\section{5. 四脚移動ロボットの歩行実験}

第4章の ON-OFF 入出力タイミング信号を用いて四脚移動 ロボットの歩行実験を行った。ロボットの歩行軌跡と移動距離 を図 10 に示す.ロボットは軸脚を入れ替える時に一瞬バランス を崩し後退するものの, 転倒することなく歩行することが確認 された. また, 同図に示寸ように本機は，60 秒で約 $25 \sim 30 \mathrm{~mm}$ 前進し，平均速度は約 $0.45 \mathrm{~mm} / \mathrm{s}$ であった。このように, SMA と柔軟プレートを組み合わせた FFPアクチュエータをボディの 内側へとそれぞれ可変させることで推進力を得ることができる. これは, 比較的単純な機能を持つデバイスとして高く評価でき るものと考える. しかしながら, 歩行実験を繰り返した結果, 遊脚から支持脚へと切り替わる時点で安定余裕が著しく低下寸 るという問題が生じ，これが信号タイミングに大きな影響を及 ぼした．そこで, 脚形状において, 脚先と脚元の位置が常に一 直線上になるように SMA を鉛直に固定し, プーリを用いてテン ションが低下しない構造へと改善した. 次に, 移動ロボットに 課せられる課題として, センサやバッテリーなどの重量物を搭 載することを想定したペイロード実験を行った。ペイロード実 験の様子を図 11 に示す. 重量物を搭載するエリアとして, ロボ ットが安定して歩行するように胴体下中央部にスペースを設け た。ここに負荷を加えて歩行を試みた。負荷は，0.01N，0.02N と徐々に加え, 不安定な動作が見られた時点で, 小刻みな負荷 調整を行った. 図 12 にペイロード実験の結果を示す. 移動距離 は 30 秒に対し， $0.03 \mathrm{~N}$ では $38 \mathrm{~mm} ， 0.06 \mathrm{~N}$ では $43 \mathrm{~mm}, 0.1 \mathrm{~N}$ では $48 \mathrm{~mm}$ と安定して距離を延ばした。しかしながら，0.13N の負荷時では，姿勢が左右に大きく摇れるようになり，不安定 な姿勢のまま $15 \mathrm{~mm}$ まで歩行した。 そして，0.15Nでロボット

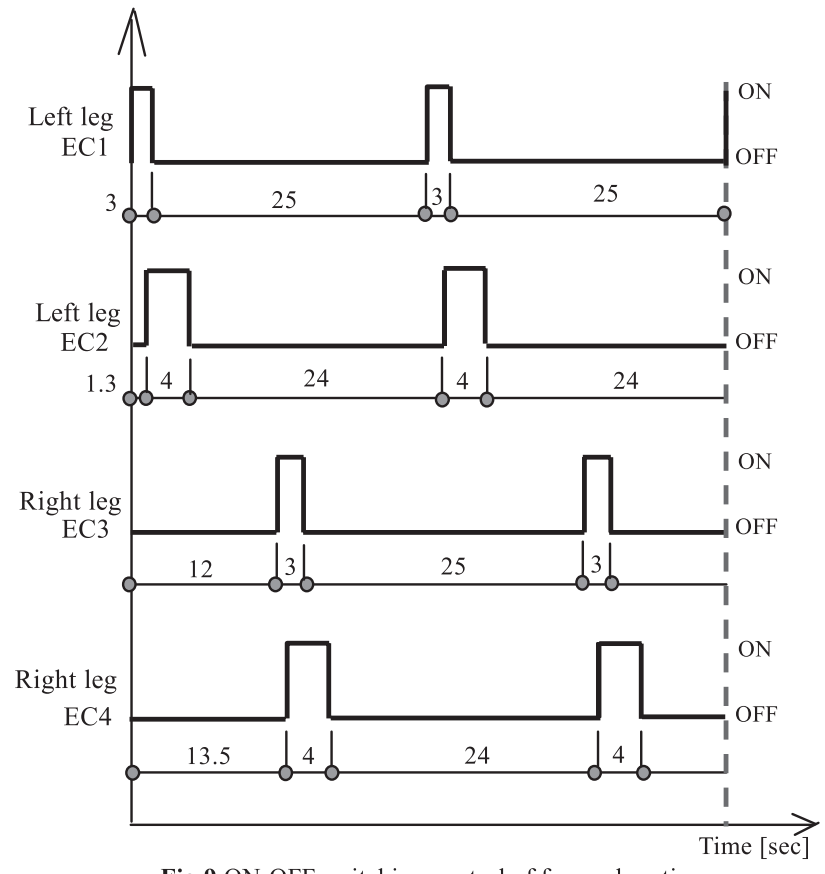

Fig.9 ON-OFF switching control of forward motion 


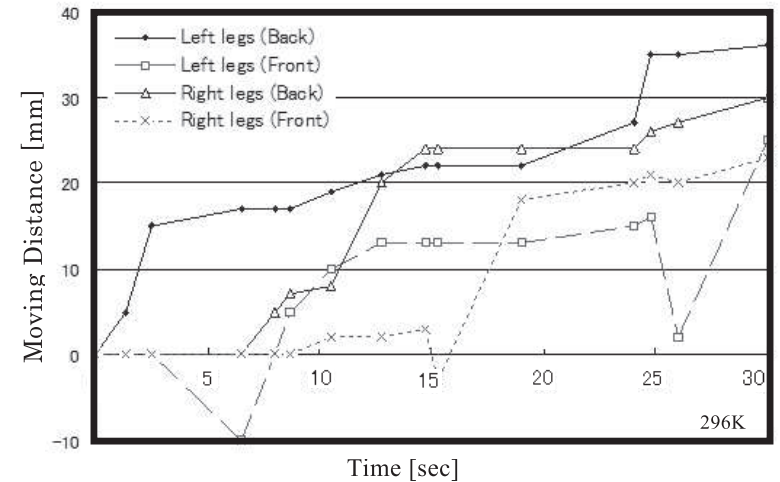

Fig.10 Trajectories of Flexible quadruped locomotion robot

は歩行不可能と観測された。一方で，0N では，30 秒で $30 \mathrm{~mm}$ 以上の移動距離を示したが，負荷を加えることにより約 1.3 倍 の距離を伸ばすことができた。これは，体を支える上で重要な 脚の摩擦力が増したことで安定した歩行が得やすくなったもの と考える. 逆に, $0.13 \mathrm{~N}$ ，すなわち， $13 \mathrm{~g}$ 以上の重量物を搭載す ると, SMA の伸縮によるプレートの曲げ効果が十分に発揮され なくなる. よって, ロボットは自重 $(5.7 \mathrm{~g})$ の約 1.3 倍程度の負 荷において動作可能であった，仮に，試作したロボットで，こ れ以上の重量を積載する時は, アクチュエータの数を増やすこ とや脚の強化改善が求められる.

\section{6. 結言}

本研究では, 液ガスなどの腐食性が強い場所や高低温領域で 利用できる脚式移動ロボットとして, SMA と薄いポリエチレン プレートで構成された FFPアクチュエータを製作し，これをロ ボットの駆動源および脚として利用することで四脚移動ロボッ トの移動手段を手に入れた，次に，四脚移動ロボットの歩行に 必要な歩容生成について提案し, 単純な ON-OFF 制御で歩行す るための入出力信号タイミングについて実験的に明らかにした. さらに，歩行実験とペイロード実験について評価を行い，ロボ ットに負荷を与えたときの移動の軌跡と歩行の影響について検 討を加えた. 本研究で得られた知見を以下のようにまとめる.

（1） SMA と柔軟プレートを組み合わせた FFPアクチュエータ をボディの内側へとそれぞれ可変させることで推進力を得 る全高約 $80 \mathrm{~mm}$, 横幅約 $45 \mathrm{~mm}$, 奥行幅約 $50 \mathrm{~mm}$, 総質量 約 $5.7 \mathrm{~g}, 3.0 \mathrm{~V} / 0.7 \mathrm{~A}$ で駆動する四脚移動ロボットを開発し た.

(2) 四脚移動ロボットは, 単純な ON-OFF 入出力タイミング駆 動によって転倒することなく歩行を達成し, 30 秒で $30 \mathrm{~mm}$ 以上の移動を行った.

（3）ペイロード実験では, 自重(5.7g)の約 1.3 倍程度の負荷でも 歩行可能であった.

今後の課題として, ロボットに ON-OFF 入出力信号タイミン グを連続的に繰り返すと, 床面の微小なガタや SMA が持つヒス テリシスによって歩行に乱れを生じる傾向がある．特に本ロボ ットは, 脚自身が本体構造部材を兼ねているため, 周囲温度が 変化しても移動に必要な力積を得られるように考慮しなくては ならない，そこで，SMA 自体が持つ温度ヒステリシスを相殺で きるような構造およびON-OFF信号タイミングについて具体的 に検討を行う予定である.

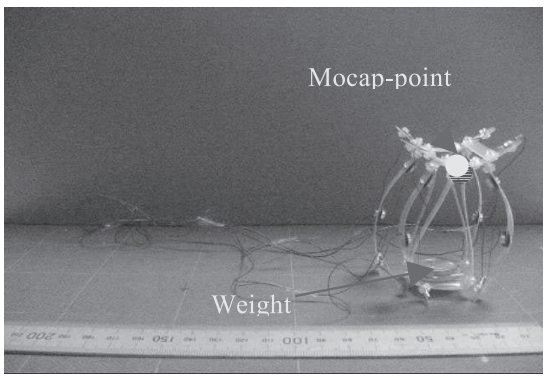

Fig.11 Payload experiments (upper and lower area)
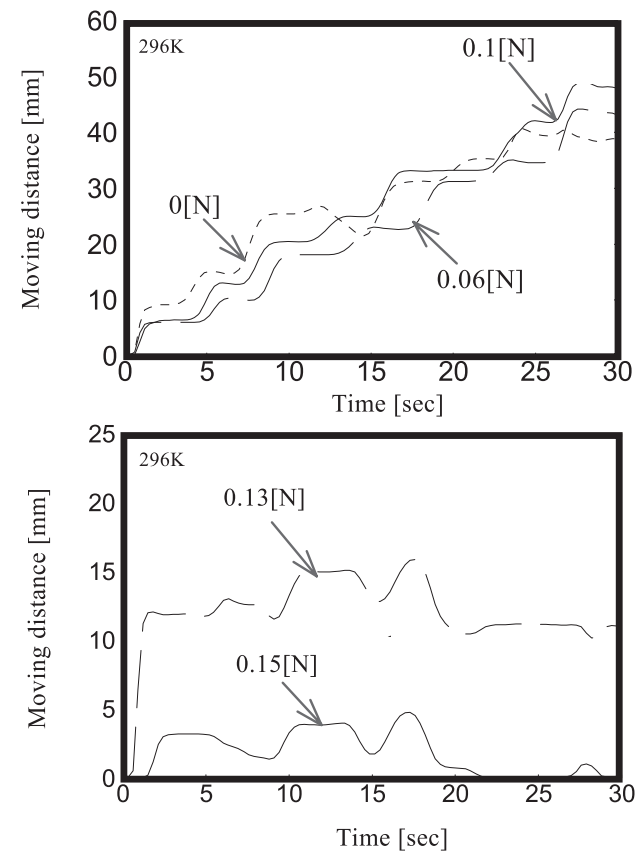

Fig.12 Trajectories of robot (Apply load)

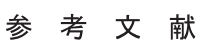

1) 橋本 稳, 戸子田勉, 田畑 毅, 中村仁彦：“形状記憶合金を用いた腹 腔鏡下外科手術のための能動鉗子機構” , 日本ロボット学会誌, Vol. 17, No. 4, pp. 513-519, 1999.

2) 中村仁彦, 清水和利：“低侵襲外科手術用光駆動 SMA 能動鉗子”, 日 本ロボット学会誌, Vol. 17, No. 3, pp. 439〜448, 1999.

3）細田裕司，他：“形状記憶合金を応用した 3 本指ロボットハンド” 第一回日本ロボット学会学術講演概要集, pp.213-214.1983.

4) T.Hino, T. Maeno : "Development of Miniature Robot Finger with a Variable Stiffness Mechanism using Shape Memory Alloy" , Proc. International Symposium on Robotics and Automation, 2004.

5）杉山勇太, 平井慎一：“柔軟ロボットの変形を用いた移動と跳躍”, 日本ロボット学会誌, Vol. 24, No. 3, pp. 378-387, 2006.

6）納富 充雄, 長谷川久夫, 下坂 陽男, 江原 信郎, “形状記憶合金を用い た微小歩行機構のはり理論による最適設計”，日本設計工学 会, Vol. 35, No5, pp. 221-225, 2002.

7）野口晋也，松下徹平，村上純一，西田麻美，“柔軟ロボットに関す るF F Pアクチュエータの応答速度の向上”第 11 回計測自動制御 学会 (SI2010), pp. 762-763, 2010.

8) Chee Siong Loh, et al. : "A New Heating Method for the Actuation of the Shape Memory Alloy (SMA) Actuator" , The 9th International Conference on Inte11igent Autonomous Systems 9 (IAS-9), IOS Press, ISBN 1-58603-595-9, pp. 839-846, 2006.

9) Y. Takahashi, M. Tsuji, J. Sakurai, H. Hosoda, K. Wakashima and S. Miya -zaki:Trans. Mat. es. Soc. Jpn. , 28, (2003) 627-630.

10) A. Sandu, K. Tsuchiya, D. Tomus, Y. Todaka, M. Umemoto. " Influenceof heat treatments on mechanical properties and transformation temperatures in $\mathrm{Ti}-\mathrm{Ni}-\mathrm{Zr}$ alloys” 日本金属学会, 講演概要集 pp. 402, 2005. 